\title{
Efektivitas Metode Token Economy dalam Terapi Perilaku untuk Menurunkan Gejala Hambatan Perkembangan Sosial pada Anak Usia Dini
}

\author{
Mumtaz Afridah \\ Program Studi Bimbingan Konseling Islam, Fakultas Ushuluddin Adab dan Dakwah, \\ IAIN Syekh Nurjati Cirebon \\ amoratirza@gmail.com
}

\begin{abstract}
Abstrak
Hambatan perkembangan sosial adalah kondisi perkembangan sosial yang terjadi pada anak tidak sesuai dengan tahapan pencapaian perkembangan sosial di usianya. Penelitian ini bertujuan untuk mengetahui efektivitas dari terapi perilaku dengan metode token economy dalam menurunkan gejala hambatan perkembangan sosial pada anak usia dini. Terapi perilaku dengan metode token economy disusun sebagai upaya untuk menurunkan gejala hambatan sosial yang dimunculkan saat berinteraksi di sekolah. Penelitian ini menggunakan metode penelitian kualitatif single case experimental desain A-B-A. Teknik sampling yang digunakan adalah teknik purposive sampling yang didasarkan pada pertimbangan tertentu. Adapun responden dalam penelitian ini adalah anak dengan gejala hambatan perkembangan sosial yang belum pernah mendapatkan terapi perilaku sebelumnya. Hasil penelitian menunjukkan bahwa pemberian terapi perilaku dengan metode token economy dapat menurunkan gejala hambatan perkembangan sosial.
\end{abstract}

Kata Kunci: Token Economy; Hambatan Sosial; Terapi Perilaku.

\section{PENDAHULUAN}

Hambatan perkembangan sosial adalah kondisi di mana perkembangan sosial yang terjadi pada individu dalam hal ini khususnya anak tidak sesuai dengan tahapan pencapaian perkembangan sosial di usianya. Sesungguhnya, Santrock (2002) menjelaskan bahwa pada proses awal yaitu pada masa anak-anak umur 2-6 tahun, anak belajar melakukan hubungan sosial dan bergaul dengan orang-orang di luar lingkungan rumah, terutama dengan anakanak yang usianya sebaya. Anak belajar menyesuaikan diri dan bekerja sama dalam kegiatan bermain. Pada masa ini, sejumlah hubungan yang dilakukan anak dengan anak-anak lain meningkat dan ini sebagian menentukan bagaimana gerak maju perkembangan sosialnya.

Menurut Hurlock (1997) bentuk perilaku sosial yang paling penting untuk penyesuaian sosial mulai berkembang dalam periode awal masa anak-anak, yaitu pada fase 
usia empat tahun di mana individu mulai memiliki pengalaman sosialisasi pendahuluan, biasanya ia mengerti dasar-dasar permainan kelompok, sadar akan pendapat orang lain dan berusaha memperoleh perhatian dengan cara berlagak menonjolkan diri. Dalam usia di tahun-tahun selanjutnya, anak seharusnya mampu memperhalus perilaku sosialnya dan mempelajari pola perilaku baru yang lebih dapat diterima oleh kelompok teman-temannya. Namun, tidak semua anak dapat sukses melewati tugas perkembangannya dengan baik. Hal ini dipengaruhi oleh banyak hal, diantaranya adalah pengaruh keluarga, baik pola asuh, kecenderungan keluarga, dan pemberian stimulasi dari orangtua, serta pengaruh lingkungan luar, seperti pertemanan.

Pada penelitian ini, peneliti mendapatkan responden pada populasi TK di Yogyakarta dengan inisial A yang dikeluhkan oleh gurunya bahwa ia sulit untuk berpisah dengan orangtua ketika berada di sekolah. A sangat pemalu dan cenderung menginginkan ibunya untuk berada di dalam kelas. A sebenarnya masih ada keinginan untuk dekat dengan temantemannya, namun sangat jarang, dan cenderung bersama ibunya saat istirahat serta tidak mau berkumpul dengan teman teman. Guru pun mengatakan bahwa orangtua A adalah orangtua yang pencemas dan cenderung melarang anaknya untuk bermain di taman.

Terhambatnya perkembangan sosial pada anak memiliki dampak yang negatif pada kemampuan anak dalam menyesuaikan diri pada lingkungan sosial di kemudian hari (Rohayati, 2013). Selain itu, perkembangan sosial yang terhambat pada anak berpengaruh pula perkembangan kemampuan verbalnya. Oleh karena itu, penting untuk diberikannya intervensi yang tepat bagi responden sehingga dampak dari hambatan perkembangan sosial ini dapat diminimalisir. Terapi perilaku efektif memberikan pengaruh terhadap penurunan perilaku hiperaktivitas pada anak GPPH. Oleh karena itu, pada penelitian ini pun pendekatan yang digunakan dalam intervensi ini adalah pendekatan perilaku. Pendekatan perilaku dianggap paling efektif dibandingkan pendekatan lain dikarenakan pendekatan ini langsung menarget pada perilaku yang ingin diubah (Paternote \& Buitelaar, 2010). Terapi perilaku seperti pemberian penguat positif untuk perilaku yang baik, terbukti sangat efektif dalam mengurangi gejala yang nampak (Schellack \& Meyer, 2016).

Hanya saja pada kasus ini, lebih menekankan pada anak dengan hambatan perkembangan sosial. Selain itu, teknik yang digunakan pada klien adalah token economy yang memfokuskan pada pemberian token kepada responden dan pemberian pengajaran kepada ibu dan guru terkait token economy. Token economy (Zirpoli, 2012) adalah suatu teknik dalam pendekatan perilaku yang memberikan token sebagai penguat untuk suatu perilaku. Token ini akan ditukarkan jika perilaku telah dimunculkan. Menurut Uams (Thiegbulem dkk, 2011), salah satu motivasi yang dapat membuat seorang pelajar mau untuk belajar adalah dengan pemberian token economy. Theighbulem, dkk. (2011) menyatakan dalam penelitiannya bahwa token economy mampu meningkatkan prestasi akademik siswa. Hal itu terjadi karena dengan token economy siswa diupayakan dapat belajar.

Pemberian intervensi pada penelitia ini pun memperhatikan beberapa faktor yang mempengaruhi perkembangan sosial anak menurut Daeng (1996) salah satunya adalah 
adanya role model yang mengajarkan anak untuk dapat bersosialisasi, oleh karena itu, intervensi ini pun berupaya memberikan insight kepada orangtua terkait minat dan perilaku mereka dalam bersosialisasi. Oleh karena itu, sebelum upaya pemberian intervensi kepada klien diberikan, orangtua terlebih dahulu mendapatkan intervensi berupa konseling kognitif untuk menurunkan kecemasannya dan psikoedukasi terkait perkembangan anak sehingga orangtua dapat menjadi partner bagi pencapaian perkembangan klien.

\section{METODE PENELIAN}

Penelitian ini menggunakan metode penelitian kualitatif single case experimental desain A-B-A. Menurut Kazdin (dalam Latipun, 2010), single case experimental adalah sebuah desain penelitian untuk mengevaluasi efek suatu perlakuan dengan kasus tunggal. Kasus tunggal pada penelitian ini adalah gejala hambatan sosial pada anak usia dini. Kita akan membandingkan hasil pengamatan pada fase baseline pra intervensi dan fase baseline pasca intervensi. Penelitian ini akan menjadikan gejala perilaku hambatan sosial sebagai variabel tergantung dan terapi perilaku dengan metode token economy sebagai variabel bebas.

Teknik sampling yang digunakan adalah teknik purposive sampling yang didasarkan pada pertimbangan tertentu (Sugiono, 2017). Responden pada penelitian ini adalah anak dengan gejala hambatan perkembangan sosial. Karakteristik responden dalam penelitian ini yaitu anak dengan hambatan sosial yang dilihat dari rendahnya skor aspek sosialisasi pada tes VSMS (Vineland Social Maturity Scale) serta hasil screening KPSP yang menunjukkan perkembangan yang meragukan, khusunya dalam aspek perkembangan sosial dan kemandirian. Berikut deskripsi profil responden:

Tabel 1. Profil Responden

\begin{tabular}{ll}
\hline Nama (Inisial) & A \\
\hline Jenis Kelamin & Laki-Laki \\
Tempat Tanggal Lahir & Sleman, 22 Juli 2010 \\
Usia & 4 Tahun 6 Bulan 2 Hari (per 24 Janurai 2017) \\
Urutan Kelahiran & Anak ke 1 dari 1 bersaudara \\
\hline
\end{tabular}

\section{Teknik Pengumpulan Data}

Pertama, peneliti melakukan wawancara yang dilakukan kepada guru responden dan orang tua responden, Kedua, melakukan pengumpulan data menggunakan metode observasi kepada responden saat di sekolah maupun di rumah. Ketiga, peneliti melakukan penegakan diagnosis dengan mengambil data berdasarkan Kuesioner Pra Skrining Perkembangan (KPSP). Kuesioner ini diberikan kepada responden dengan cara ditanyai dan diamati oleh peneliti sesuai aspek usia responden. Selain itu, diberikan pula tes VSMS (Vineland Social Maturity Scale) untuk mengetahui kematangan sosialnya, serta untuk mengetahui intelegensi menggunakan BINET sebagai data penunjang diagnosis, sehingga diagnosis dapat tegak bukan karena adanya pengaruh dari intelegensi. Keempat, pengambilan data kembali dengan observasi dan wawancara pasca intervensi. 


\section{Teknik Pemberian Intervensi}

Responden akan diberikan intervensi selama 2 minggu, setiap harinya intervensi dilakukan selama 3 jam di sekolah. Intervensi yang dilakukan kepada responden menggunakan terapi perilaku dengan teknik tokens economy. Token economy merupakan teknik di mana perilaku-perilaku yang diinginkan diberikan penguatan oleh tokens (kepingin logam atau kartu berwarna dan bertanda) yang dapat digunakan siswa untuk "membeli" berbagai penguat lain (Omrod, 2009). Prinsip penggunaan token economy adalah memotivasi individu untuk melakukan perilaku yang ditargetkan, sehingga memperoleh token dan dapat ditukarkan dengan backup reinforcer yang telah ditetapkan sebelumnya (Sundel \& Sundel, 2005). Responden akan melewati beberapa tahap seperti penentuan perilaku yang diharapkan, lalu penentuan tokens, dan kesepakatan mengenai kapan tokens diberikan, sampai proses pemantauan terhadap perilaku yang diharapkan.

\section{Tabel 2. Langkah Implementasi Token Economy}

\begin{tabular}{|c|c|c|}
\hline No. & $\begin{array}{l}\text { Langkah } \\
\text { Implementasi Token } \\
\text { Economy }\end{array}$ & Langkah Implementasi Token Economy Klien \\
\hline 1. & $\begin{array}{l}\text { Memutuskan Perilaku } \\
\text { Target }\end{array}$ & $\begin{array}{l}\text { a. Memunculkan perilaku mandiri dalam melakukan } \\
\text { kegiatan urus diri di sekolah. } \\
\text { b. Memunculkan perilaku mandiri dalam melakukan } \\
\text { pengerjaan tugas. } \\
\text { c. Membuat klien mau berada dalam jarak } 1,5 \text { meter } \\
\text { dengan ibu. } \\
\text { d. Membuat klien mau berada dalam jarak } 3 \text { meter } \\
\text { dengan ibu. } \\
\text { e. Membuat klien berada di kelas sendiri dan ibu di luar } \\
\text { felas. } \\
\text { f. Membuat klien mau ditinggal ibu di sekolah. }\end{array}$ \\
\hline 2. & Menentukan Baseline & $\begin{array}{l}\text { a. A sering merengek agar orangtua mengerjakan } \\
\text { tugasnya. } \\
\text { b. A selalu ditemani orangtua saat di kelas. }\end{array}$ \\
\hline 3. & $\begin{array}{l}\text { Memilih Jenis Token } \\
\text { Yang Digunakan }\end{array}$ & $\begin{array}{l}\text { a. Token yang diberikan kepada klien adalah berupa } \\
\text { stiker binatang. } \\
\text { b. Token akan diberikan ketika klien menunjukkan } \\
\text { kesesuaian dengan perilaku target. } \\
\text { c. Token diberikan pada tiap akhir pertemuan (pulang } \\
\text { sekolah). }\end{array}$ \\
\hline 4. & $\begin{array}{l}\text { Memilih Penguat } \\
\text { Sekunder }\end{array}$ & Jenis penguat sekunder yang diberikan adalah makanan. \\
\hline 5. & $\begin{array}{l}\text { Mengelola Penguat } \\
\text { Sekunder }\end{array}$ & $\begin{array}{l}\text { Penguat sekunder akan diberikan apabila klien mampu } \\
\text { mengumpulkan token (stiker binatang) minimal tiga dari } \\
\text { lima token dalam tiap sesi. }\end{array}$ \\
\hline 6. & $\begin{array}{l}\text { Mengidentifikasi } \\
\text { Bantuan Yang Terdiasa }\end{array}$ & $\begin{array}{l}\text { Orangtua membantu dalam menerapkan token economy } \\
\text { kepada klien }\end{array}$ \\
\hline
\end{tabular}


Wali kelas pun berperan dalam memberi stimulus dan dorongan agar perilaku nampak.

\begin{tabular}{|c|c|c|}
\hline 7. & $\begin{array}{l}\text { Mengatasi Potensi } \\
\text { Manusia }\end{array}$ & $\begin{array}{l}\text { Untuk mengantisipasi adanya potensi masalah, } \\
\text { pelaksanaan token economy dipertimbangkan secara } \\
\text { matang. Selain itu, token hanya dimiliki oleh praktikan } \\
\text { sehingga menutup kemungkinan terjadinya manipulasi } \\
\text { token. }\end{array}$ \\
\hline 8. & $\begin{array}{l}\text { Mempersiapkan } \\
\text { Manual }\end{array}$ & $\begin{array}{l}\text { Manual pelaksanaan token economy digabungkan dengan } \\
\text { pembelajaran klien. }\end{array}$ \\
\hline
\end{tabular}

\section{Analisis Data}

Data yang ada dianalisis menggunakan analisis fungsional model ABC menurut Kahn (1999). Analisis ini mengunakan elemen Antecendents, Behaviour dan Concequences $(\mathrm{ABC})$. Analisis ini biasa digunakan dalam upaya perubahan perilaku dengan cara mencari baseline awal sebelum intervensi dan dianalisis kembali dengan mencari baseline setelah intervensi.

\section{HASIL DAN PEMBAHASAN}

\section{Hasil Penelitian}

Berdasarkan hasil pemeriksaan dengan menggunakan Kuesioner Praskrining Perkembangan (KPSP) diperoleh jumlah jawaban benar sebanyak 8 yang artinya klien berada dalam kategori perkembangan meragukan (M). Kategori ini memungkinkan adanya tahap perkembangan yang dinilai kutrang optimal pada diri klien, sehingga terdapat beberapa intervensi lanjutan yang perlu diberikan kepada klien.

\section{Tabel 3. Hasil KPSP}

\begin{tabular}{c|c|c|c|c}
\hline No. & Aspek Perkembangan & $\begin{array}{c}\text { Soal yang } \\
\text { disajikan }\end{array}$ & Skor Jawab & Jumlah Benar \\
\hline $\mathbf{1 .}$ & Bicara dan Bahasa & $\mathbf{3}$ & $\mathbf{3}$ & $\mathbf{3}$ \\
\hline $\mathbf{2 .}$ & Gerak Kasar & $\mathbf{1}$ & $\mathbf{1}$ & $\mathbf{1}$ \\
\hline $\mathbf{3 .}$ & Gerak Halus & $\mathbf{3}$ & $\mathbf{3}$ & $\mathbf{3}$ \\
\hline $\mathbf{4 .}$ & Sosial dan Kemandirian & $\mathbf{3}$ & $\mathbf{1}$ & $\mathbf{1}$ \\
\hline \multicolumn{4}{c}{ Total } \\
\hline
\end{tabular}

Terdapat 4 aspek yang diamati dalam KPSP, yaitu bicara dan bahasa, gerak halus, gerak kasar, dan sosial keamandirian. Setiap aspeknya diukur berdasarkan tugas perkembangan sesuai dengan usia klien. Apabila kita lihat berdasar pada tabel hasil KPSP diatas, ditunjukkan pada aspek sosial kemandirian, klien tidak dapat menyelesaikan keseluruhan pertanyaan. Klien hanya mampu menjawab 1 pertanyaan dari 3 pertanyaan yang ada. Hal ini menunjukkan bahwa klien perlu memaksimalkan perkembangan pada aspek tersebut. Klien masih perlu memaksimalkan kemandiriannya dengan mengurus diri sendiri, serta bersosialisasi, dan berinteraksi dengan lingkungannya. 
Tabel 4. Hasil Tes VSMS

\begin{tabular}{|c|c|c|c|c|}
\hline No. & Aspek & $\begin{array}{c}\text { Jumlah } \\
\text { Soal }\end{array}$ & Jumlah Poin & $\begin{array}{c}\text { Jumlah Poin: Jumlah } \\
\text { Soal }\end{array}$ \\
\hline 1. & Communication (C) & 10 & 9 & 0,75 \\
\hline 2. & Socialization $(\mathrm{S})$ & 9 & $21 / 2$ & 0.3 \\
\hline 3. & Self Help General (SHG) & 14 & 12 & 0.86 \\
\hline 4. & Self Help Eating (SHE) & 11 & 8 & 0.73 \\
\hline 5. & Self Help Dressing (SHD) & 12 & $81 / 2$ & 0.7 \\
\hline 6. & Self-Direction (SD) & 1 & 0 & 0 \\
\hline 7. & Occupation $(\mathrm{O})$ & 10 & $51 / 2$ & 0.55 \\
\hline 8. & Locomotion $(\mathrm{L})$ & 7 & 5 & 0.7 \\
\hline \multicolumn{3}{|c|}{ Social Quotion } & \multicolumn{2}{|l|}{87.2} \\
\hline \multicolumn{3}{|c|}{ Kategori SQ } & \multicolumn{2}{|c|}{$\begin{array}{l}\text { Kematangan sosial kurang sesuai usia } \\
\text { yang dimiliki saat ini. }\end{array}$} \\
\hline
\end{tabular}

Berdasarkan tabel hasil tes VSMS (Vineland Social Maturity Scale) di atas, A memiliki skor kematangan sosial yakni 87.2, apabila dibandingkan dengan usia aslinya skor tersebut dikategorikan kurang sesuai, artinya, kematangan sosial klien kurang sesuai dengan usia yang dimilikinya saat ini.

\section{Hasil Tes Intelegensi}

A memiliki perkembangan kognitif yang setara dengan usianya. A memiliki skor intelegensi sebesar 103 (Skala BINET). Skor tersebut tergolong normal dan termasuk kategori rata-rata artinya A memiliki kemampuan yang setara dengan kemampuan anak seusianya. Kemampuan A yang cenderung lebih baik dari kemampuan lainnya adalah kemampuan perbendaharaan kata dan kelancaran verbal. Kemampuan bahasa yang baik berpengaruh pada kemampuan A dalam pemahaman, karena dengan memahami bahasa A cenderung mudah untuk memahami informasi yang ia tangkap. Dengan kapasistas intelektual dan kemampuan pemahaman yang baik, A pun memiliki kemampuan penalaran yang juga cukup baik. A juga memiliki usia mental yang lebih tinggi dari usia kronologis A. Usia mental A adalah 4 tahun 8 bulan sementara usia kronologisnya adalah 4 tahun 6 bulan 2 hari. Hal ini menunjukkan bahwa A tidak tergolong memiliki hambatan secara mental.

\section{Tabel 5. Hasil Analisis Perilaku}

\begin{tabular}{l|l}
\hline \multicolumn{1}{c|}{ Baseline } & \multicolumn{1}{c}{ Pascaintervensi } \\
\hline $\begin{array}{l}\text { A cenderung menyendiri, bermain sendiri } \\
\text { dan selalu berdekatan dengan ibunya. }\end{array}$ & $\begin{array}{l}\text { A mau bergabung dengan teman, mendekati } \\
\text { teman, mengajak berbincang dan melakukan } \\
\text { beberapa permainan. }\end{array}$ \\
\hline $\begin{array}{l}\text { A tidak suka merespon ucapan teman saat } \\
\text { bermain padahal ia dapat berbicara dengan } \\
\text { lancar. }\end{array}$ & A merespon ucapan teman saat bermain. \\
\hline $\begin{array}{l}\text { A tidak suka berbagi mainan dengan teman } \\
\text { dan memarahi teman yang meminjam } \\
\text { mainan. }\end{array}$ & $\begin{array}{l}\text { A bermain bersama dengan mainan yang } \\
\text { sama dan saling bergantian. A berani } \\
\text { memberikan kue kepada teman. }\end{array}$ \\
\hline
\end{tabular}




\begin{tabular}{|c|c|}
\hline $\begin{array}{l}\text { A tidak mau membantu teman membereskan } \\
\text { mainan yang sudah digunakan bersama. }\end{array}$ & $\begin{array}{l}\text { A bersemangat untuk merapihkan mainan } \\
\text { dan berkata "aku aja yang bereskan!Ini aku } \\
\text { yang bereskan!" }\end{array}$ \\
\hline $\begin{array}{l}\text { A disuapi oleh ibunya dan memakai sepatu } \\
\text { oleh ibunya. }\end{array}$ & $\begin{array}{l}\text { A makan sendiri, membuang sampah sendiri, } \\
\text { mencuci tangan sendiri, memakai sepatu } \\
\text { sendiri, mengerjakan tugas beberapa kali } \\
\text { tidak dibantu. Mengembalikan tugasnya } \\
\text { sendiri ke depan kelas. }\end{array}$ \\
\hline A tidak suka merespon ucapan ibu guru. & $\begin{array}{l}\text { A menjawab pertanyaan ibu guru baik saat } \\
\text { pelajaran atau sedang ditanya. }\end{array}$ \\
\hline $\begin{array}{l}\text { A pun tidak pernah maju kedepan kelas } \\
\text { ketika semua teman antusias dengan cerita } \\
\text { ibu guru. }\end{array}$ & $\begin{array}{l}\text { A maju kedepan kelas dengan antusias ketika } \\
\text { ibu guru menjelaskan sesuatu. }\end{array}$ \\
\hline A selalu ditemani orangtua saat di kelas. & $\begin{array}{l}\text { A mau berjarak dengan ibunya walau hanya } \\
1,5 \text { meter. A pun mau menjauh dari ibunya } \\
\text { untuk duduk di depan ketika salah satu teman } \\
\text { berulang tahun. }\end{array}$ \\
\hline $\begin{array}{l}\text { A sering merengek agar orangtua } \\
\text { mengerjakan tugasnya. }\end{array}$ & $\begin{array}{l}\text { A mau mengerjakan tugasnya hingga selesai } \\
\text { tanpa banyak dibantu ibu. }\end{array}$ \\
\hline
\end{tabular}

\section{Hasil Intervensi Orang Tua}

Intervensi kepada guru diberikan dalam bentuk psikoedukasi dan konseling. Hasil intervensi pun ditunjukkan pada skor pra dan pasca tes psikoedukasi yang diberikan pada orangtua responden. Berikut hasil yang ditunjukan:

Grafik 1. Hasil Psikoedukasi Orangtua

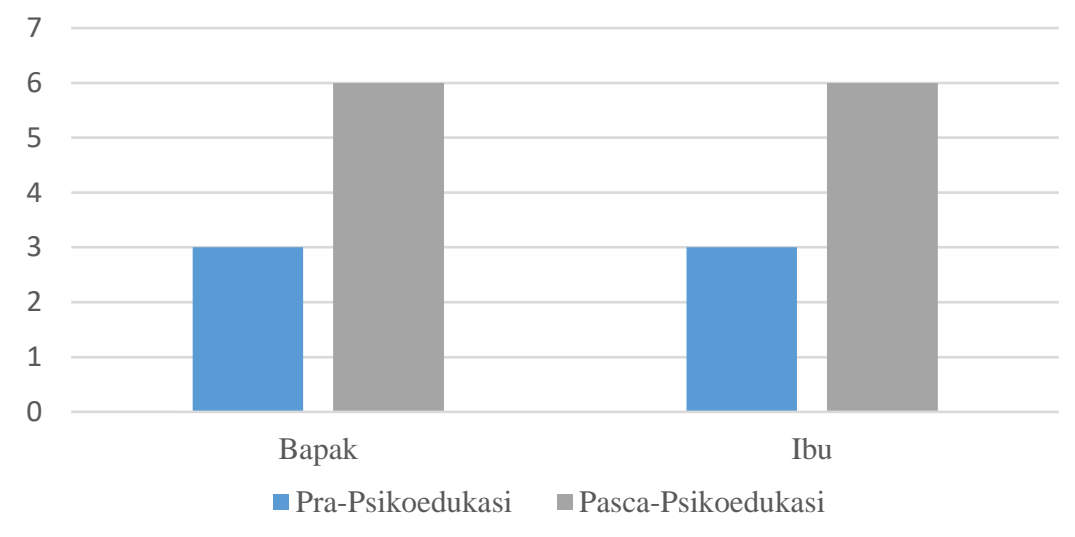

Berdasarkan grafik di atas ditunjukkan bahwa terdapat peningkatan pengetahuan orangtua, baik bapak dan ibu mengenai kondisi perkembangan klien. Pengetahuan orangtua menjadi salah satu faktor yang berpengaruh terhadap pencapaian tugas perkembangan anak. 
18 | Afridah - Efektivitas Metode Token ...

Tabel 6. Evaluasi Hasil Intervensi Orangtua

\begin{tabular}{l|l}
\hline \multicolumn{1}{c|}{ Prakonseling } & \multicolumn{1}{c}{ Pascakonseling } \\
\hline $\begin{array}{l}\text { Orangtua belum mengetahui mengenai } \\
\text { kondisi klien berdasarkan hasil } \\
\text { asesmen. }\end{array}$ & $\begin{array}{l}\text { Orangtua memahami kelebihan } \\
\text { maupun kelemahan yang ada dalam } \\
\text { diri klien. }\end{array}$ \\
\hline $\begin{array}{l}\text { Orangtua belum mengetahui } \\
\text { perkembangan anak usia 54 bulan. }\end{array}$ & $\begin{array}{l}\text { Orangtua memahami perkembangan } \\
\text { anak usia 54 bulan. }\end{array}$ \\
\hline $\begin{array}{l}\text { Orangtua belum benar-benar } \\
\text { memahami faktor-faktor yang } \\
\text { mempengarui perkembangan klien, } \\
\text { baik yang menghambat maupun yang } \\
\text { meningkatkan. }\end{array}$ & $\begin{array}{l}\text { Orangtua menyadari faktor-faktor } \\
\text { yang mempengarui perkembangan } \\
\text { klien, baik yang menghambat } \\
\text { maupun yang meningkatkan. }\end{array}$ \\
$\begin{array}{l}\text { Orangtua belum benar-benar } \\
\text { mengetahui metode yang dapat } \\
\text { diterapkan untuk menangani hambatan } \\
\text { pada klien. }\end{array}$ & $\begin{array}{l}\text { Orangtua mengetahui dan memilih } \\
\text { metode yang dapat diterapkan untuk } \\
\text { menangani hambatan pada klien } \\
\text { serta mau bekerjasama dalam proses } \\
\text { intervensi. }\end{array}$ \\
\hline $\begin{array}{l}\text { Orangtua belum mengetahui hal-hal } \\
\text { yang tidak sebaiknya dilakukan dan } \\
\text { sebaiknya dilakukan untuk anak. }\end{array}$ & $\begin{array}{l}\text { Orangtua menyadari hal yang } \\
\text { seharusnya tidak dilakukan dan } \\
\text { seharusnya dilakukan olehnya. }\end{array}$ \\
\hline
\end{tabular}

Intervensi pula diberikan khusus kepada ibu klien dengan diberikan konseling kognitif. Berikut rangkuman hasil intervensi yang dibandingkan dengan kondisi sebelum dan setelah diberi konseling:

Tabel 7. Evaluasi Hasil Konseling Ibu

\begin{tabular}{l|l}
\hline \multicolumn{1}{c|}{ Prakonseling } & \multicolumn{1}{c}{ Pascakonseling } \\
\hline $\begin{array}{l}\text { Ibu takut menderita penyakit kronis } \\
\text { ketika gejala-gejala kecil muncul } \\
\text { mengganggunya. }\end{array}$ & $\begin{array}{l}\text { Ibu menyadari bahwa ia tidak perlu memikirkan } \\
\text { gejala kecil yang muncul di tubuhnya, lebih baik } \\
\text { mencari tau dari artikel dan memberikan } \\
\text { pengobatan serta hidup sehat. Jika itu belum } \\
\text { kunjung sembuh dilakukan pemeriksaan. }\end{array}$ \\
\hline $\begin{array}{l}\text { Ibu takut kalau nanti tidak bisa } \\
\text { menghidupi anak-anaknya kalau } \\
\text { hamil lagi. }\end{array}$ & $\begin{array}{l}\text { Ibu menyadari jika Allah yang memberikan rezeki, } \\
\text { kalaupun ujian datang, ibu menyadari kalau Allah } \\
\text { memberikan ujian sesuai dengan batas kemampuan. }\end{array}$ \\
$\begin{array}{l}\text { Kalaupun kita tidak melangkah belum tentu ujian } \\
\text { itu tidak datang. }\end{array}$ \\
$\begin{array}{l}\text { Ibu takut jika orangtua teman klien } \\
\text { merasa kesal kalau klien tidak } \\
\text { temanjamkan mainan kepada }\end{array}$ & $\begin{array}{l}\text { lbu menyadari jika anak masih dalam masa } \\
\text { perkembangan dan masih cenderung egosentris. Ibu } \\
\text { sadar apa yang harus dilakukan untuk menurunkan } \\
\text { egosentrisnya dan menjelaskan kepada ibu teman } \\
\text { klien. }\end{array}$ \\
\hline $\begin{array}{l}\text { Ibu takut salah mendidik anaknya } \\
\text { dan membuat anaknya terluka. }\end{array}$ & $\begin{array}{l}\text { Ibu menyadari lebih baik berusaha untuk } \\
\text { memperbaiki diri dibanding harus selalu } \\
\text { memikirkan hal yang belum tentu terjadi. Ibu }\end{array}$
\end{tabular}




\begin{tabular}{l|l} 
& $\begin{array}{l}\text { menayadari bahwa ia cukup berusaha seoptimal } \\
\text { mungkin, dan menyerahkan segalan pada Allah. }\end{array}$ \\
\hline $\begin{array}{l}\text { Ibu sering menceritakan } \\
\text { ketakutannya pada anaknya. }\end{array}$ & $\begin{array}{l}\text { Ibu berusaha untuk menceritakan hal-hal yang } \\
\text { membahagiakan dan memunculkan keberanian } \\
\text { kepada anaknya. }\end{array}$ \\
\hline $\begin{array}{l}\text { Ibu sering menakut-nakuti anaknya } \\
\begin{array}{l}\text { agar anaknya menurut dan mau } \\
\text { melakukan sesuatu yang diharapkan } \\
\text { ibu. }\end{array}\end{array}$ & $\begin{array}{l}\text { Ibu berusaha untuk mencari cara lain dengan } \\
\text { memberikan reward untuk memunculkan perilaku } \\
\text { yang diharapkan dari klien. }\end{array}$ \\
\hline $\begin{array}{l}\text { Ibu takut jika anaknya berada dengan } \\
\text { orang lain sementara dia tidak ada. }\end{array}$ & $\begin{array}{l}\text { Ibu mengetahui kapan ia perlu khawatir tentang } \\
\text { keberadaan anaknya, dengan siapa dan kondisi apa. }\end{array}$ \\
\hline
\end{tabular}

\section{Hasil Intervensi Guru}

Intervensi kepada guru diberikan dalam bentuk psikoedukasi. Berikut rangkuman hasil intervensi yang dibandingkan dengan kondisi sebelum guru diberikan psikoedukasi:

\section{Tabel 8. Evaluasi Hasil Intervensi Guru}

\begin{tabular}{l|l}
\hline \multicolumn{1}{c|}{ Pra-Psikoedukasi } & \multicolumn{1}{c}{ Pasca-Psikoedukasi } \\
\hline $\begin{array}{l}\text { Wali kelas belum mengetahui mengenai } \\
\text { kondisi klien berdasarkan hasil asesmen. }\end{array}$ & $\begin{array}{l}\text { Wali kelas memahami kelebihan maupun } \\
\text { hambatan yang ada dalam diri klien. }\end{array}$ \\
\hline $\begin{array}{l}\text { Wali kelas mengetahui, namun belum benar- } \\
\text { benar mengetahui perkembangan anak usia 54 } \\
\text { bulan. }\end{array}$ & $\begin{array}{l}\text { Wali kelas mengetahui dan memahami } \\
\text { perkembangan anak usia 54 bulan. }\end{array}$ \\
\hline $\begin{array}{l}\text { Wali kelas belum benar-benar memahami } \\
\text { faktor yang mempengarui perkembangan } \\
\text { klien, baik menghambat maupun } \\
\text { meningkatkan. }\end{array}$ & $\begin{array}{l}\text { Wali kelas memahami faktor-faktor yang } \\
\text { mempengarui perkembangan klien, baik } \\
\text { yeningkatkan. }\end{array}$ \\
\hline $\begin{array}{l}\text { Wali kelas belum mengetahui ketrampilan } \\
\text { mengkonseling orangtua. }\end{array}$ & $\begin{array}{l}\text { Wali kelas mengetahui ketrampilan } \\
\text { mengkonseling orangtua. }\end{array}$ \\
$\begin{array}{l}\text { Wali kelas belum benar-benar mengetahui } \\
\text { metode yang dapat diterapkan untuk } \\
\text { menangani hambatan pada klien. }\end{array}$ & $\begin{array}{l}\text { Wali kelas belum benar-benar } \\
\text { mengetahui metode yang dapat } \\
\text { diterapkan untuk menangani hambatan } \\
\text { pada klien. }\end{array}$ \\
\hline
\end{tabular}

\section{Pembahasan}

A adalah anak yang dikeluhkan oleh gurunya sebagai anak yang sulit untuk dapat beradaptasi dengan lingkungannya. A pun sulit untuk dapat berinteraksi dengan teman di kelas maupun merespon pertanyaan guru. A cenderung pemalu dan takut, A akan bersembunyi di belakang ibunya atau mendekat kearah ibunya. Ibu A pun mengakui bahwa A sulit untuk dapat berinteraksi dengan teman-temannya, A cenderung pemalu dan menyendiri. A pun selalu meminta ibunya untuk tetap berada di kelas. Pernah suatu kali ibu A meninggalkan A pada masa orientasinya, namun A menangis tanpa berhenti, setelah itu A menjadi takut untuk sekolah dan tidak mau sekolah lagi hingga beberapa hari.

Apabila melihat tahap pencapaian perkembangan di usia A yaitu 54 bulan, A diharapkan mampu untuk berinteraksi dengan teman sebayanya dan mulai bermain dengan 
kelompoknya (Tim Penyusun Yayasan Suryakanti, 2003). Namun dalam kasus A, A sulit untuk dapat berinteraksi dengan teman-temannya dan cenderung marah jika diberi tuntutan yang sulit baginya. Pada tahap perkembangan sosial seusianya pun, seharusnya A telah mampu untuk melakukan beberapa tugas secara mandiri (Tim Penyusun Yayasan Suryakanti. 2003), sayangnya, terdapat beberapa hal yang masih belum sempurna A lakukan karena A masih bergantung pada ibunya serta ibu A pun kurang memberi kesempatan dan dorongan bagi A untuk melakukan kegiatan sendiri.

Pola perilaku sosial lainnya yang seharusnya dimunculkan di masa kanak-kanak awal adalah kemunculan sikap bangga terhadap diri dan persaingan untuk mendapatkan penerimaan sosial (Hurlock, 1997). Hal ini belum dimunculkan oleh A, A cenderung pasif dan kurang memunculkan inisiatif atau rasa keingintahuan dan upaya untuk mendapat penerimaan. A hanya diam sementara teman-teman lebih cenderung berlomba lomba untuk menjadi yang terbaik di mata ibu guru. Keinginan A untuk berbagi pun dirasa kurang, karena A sulit untuk meminjamkan mainan ataupun membagi makanan kepada temannya walaupun sudah mendapat dorongan dari orangtua. Seharusnya diusia 54 bulan, A sudah mulai untuk belajar berbagi dan menurunkan egosentrismenya serta melakukan beberapa penyesuaian yang dapat diterima secara sosial. (Hurlock, 1997).

Hurlock (1997) menjelaskan beberapa faktor yang mempengaruhi perilaku sosial, salah satu yang dialami oleh A adalah faktor keluarga dan pola asuh. Susunan keluarga menjadi salah satu faktor yang mempengaruhi perkembangan sosial, anak pertama, kedua, ketiga, maupun jumlah anggota keluarga. A adalah anak tunggal dan cucu pertama, A selalu mendapatkan perhatian yang lebih dari orangtua dan nenek kakeknya, begitu juga dengan pamannya. A sering mendapatkan beberapa hal yang dia inginkan tanpa harus banyak berusaha dan orangtua A pun cenderung memenuhi keinginan A setelah ia merengek atau memukul. Dalam konsep pendekatan behaviour, Skinner (1965) menjelaskan tentang konsep penguatan, apabila suatu perilaku mendapat penguat maka kecenderungan perilaku itu akan berulang. Dalam kasus A, A menangis dan memukul ketika menginginkan sesuatu, lalu orangtua A akan memberikan yang ia inginkan agar A terdiam. Hal ini membuat A belajar bahwa dengan menangis dan melakukan tindakan memukul, A akan mendapatkan apa yang ia inginkan. Oleh karena itu, A nampak beberapa kali merengek dan memukul ibunya ketika di kelas.

Kondisi anak tunggal yang cenderung sering mendapatkan perhatian lebih dari orangtua dan lingkungan dekatnya membuat mereka cenderung merasa sulit untuk nyaman ketika ia kurang mendapat perhatian (Hurlock,1997). Hal ini pun dirasakan oleh A sehingga A menjadi kurang merasa nyaman berada di tempat baru dengan orang yang cenderung sebaya sehingga ia tidak mendapatkan perhatian. A akan cenderung lebih merasa nyaman ketika berinteraksi dengan orang dewasa yang dapat memberikan perhatian seperti yang biasa ia dapatkan. Hal ini dapat di jelaskan dalam pendekatan behaviour Skinner (1965) bahwa suatu tingkah laku bergantung pada konsekuensi yang dimunculkan setelahnya. Apabila konsekuensi itu tidak sesuai dengan harapan, maka seseorang cenderung tidak 
mengulangi tingkah laku, begitupun sebaliknya jika tingkah laku tersebut menghasilkan konsekuensi yang sesuai harapan, seseorang cenderung mengulangi. Pada konteks A, A tidak mendakati teman sebaya karena A cenderung tidak mendapatkan perhatian yang sama yang didapatkan ketika berinteraksi dengan orang dewasa di rumahnya, di mana A cenderung mendapatkan perhatian penuh.

Sementara itu, untuk keterikatan A dengan ibu, A cenderung sulit untuk dapat berpisah dengan ibunya. Hal ini sangat wajar terjadi pada anak-anak seusia A. Salah satu faktor yang mempengaruhi kemampuan seorang anak dalam mencapai perkembangan anak adalah tempramen serta kesesuaian tempramen dan pola asuh (Santrock, 2007). A adalah anak yang cenderung memiliki tempramen slow to warm up, di mana anak dengan tempramen ini akan cenderung lebih lama untuk beradaptasi dengan lingkungan baru dan orang baru (Santrock, 2007). Apabila seorang anak dengan tempramen slow to warm up harus dihadapkan dengan tuntutan yang menekannya di mana dia diharuskan untuk segera menerima kondisi baru dan lingkungan baru secara mendadak cenderung dapat membuat anak memiliki hambatan dalam penyesuaian sosial (Santrock, 2007). Hal tersebutlah yang terjadi dalam diri A, A yang memiliki tempramen slow to warm up, diberi tuntutan secara langsung dengan meninggalkannya di sekolah tanpa tahapan tanpa adanya pembiasaan dari rumah tentang interaksi sosial membuat A cenderung terkejut dan merasa bahwa sekolah adalah ancaman sehingga $\mathrm{A}$ tidak mau bersekolah lagi apabila ibunya tidak menunggunya di kelas.

Apabila kondisi di atas dijelaskan dalam teori Skinner (1965), ibu adalah titik nyaman yang menjadi penguat positif yang dimiliki oleh A, ketika penguat positif yang membuatnya mau untuk sekolah dihilangkan hal ini dapat dilihat sebagai hukuman baginya atas perilaku baiknya, maka A pun tidak akan mengulangi perilaku baiknya, yaitu sekolah. Hal ini dijelaskan sebagai operant extincition yaitu kondisi yang terjadi ketika penguat tidak lagi dimunculkan, sehingga respon yang dimunculkan pun akan semakin berkurang dan berkurang. Oleh karena itu, apabila dikaitkan dengan kasus A, penting bagi ibu untuk membentuk titik nyaman lain sebagai penguat lain yang menjadi alternatif pilihan bagi A.

A memiliki kelekatan yang cenderung resisten dengan ibunya. Anak yang memiliki kelekatan yang resisten cenderung akan menangis dan memunculkan perilaku sangat gelisah ketika ia harus dihadapkan dengan kondisi di mana titik lekatnya dihilangkan, dan ketika ibunya datang ia akan menunjukkan protes dengan memukul dan marah kepada ibunya. A pun akan menangis dan gelisah ketika ibunya pergi dari sampingnya, ia pun akan memukul ketika ibunya kembali mendekatinya. Anak-anak dengan kelekatan resisten salah satu faktornya adalah karena orangtua kurang memberikan kesempatan bagi orang lain untuk dekat dengan anaknya terlebih mengasuhnya, sehingga sedikit sangat jarang adanya perpisahan diantara anak dan orangtua (Santrock, 2007).

Hal ini lah yang terjadi pada diri A, A setiap hari selalu bersama ibunya. Ibu A pun jarang mendorong anaknya untuk berinteraksi dengan teman-teman di lingkungan rumah. Ketika di sekolah pun, ibu A cenderung duduk, mengobrol dengan ibu lain, atau bermain hape dan membiarkan anaknya untuk diam melihat teman-temannya bermain. Selain itu, Ibu 
A pun tidak mengijinkan anaknya untuk dibawa pergi bersama neneknya atau pamannnya tanpa ditemani oleh ibu. Hal ini terjadi karena ibu A cenderung pencemas dan memberikan perlindungan yang cukup ketat kepada anaknya. Ibu A cenderung memiliki kekhawatiran terhadap banyak hal dan ibu A cenderung menceritakan kekhawatirannya pada A sehingga A cenderung terbiasa dengan perasaan takut.

Selain resonansi perasaan takut yang diberikan ibu, ibu A pun cenderung menakutnakuti A. Ketika seharusnya A memperoleh titik lekat alternatif, seperti guru dan temantemannya. Ibu A cenderung mengatakan kepada A ketika A tidak mau mengerjakan dengan kata-kata "Ayo dikerjakan, nanti ibu guru marah loh!" atau "Ayo dikerjakan, emang kamu mau ibu guru ngedeketin kamu terus?" Hal ini memberikan konsep pada A bahwa guru adalah sosok yang menakutkan dan tidak aman baginya untuk berdekatan dengan ibu guru, walaupun hal ini mampu memunculkan perilaku yang diinginkan. Dalam pendekatan behaviour Skinner (1965) dijelaskan bahwa hukuman mampu memunculkan perilaku yang diharapkan namun hukuman memberikan efek negatif yaitu membuat seseorang menjauhi titik yang memberikan hukuman. Dalam konteks ini, sosok yang memberikan hukuman dan sosok yang dianggap buruk adalah ibu guru yang seharusnya dijadikan titik aman alternatif bagi A ketika di sekolah.

\section{SIMPULAN}

Berdasarkan hasil penelitian yang telah dibahas maka disimpulkan bahwa terapi perilaku dengan metode token economy mampu menurunkan gejala hambatan sosial yang didasarkan pada tes VSMS. Akan tetapi, hasil penelitian ini tidak dapat digeneralisasi karena hanya menggunakan satu responden. Saran yang dapat diberikan bagi peneliti selanjutnya: 1) penelitian dapat menggunakan responden yang lebih banyak lagi; serta 2) penelitian dapat menggunakan metode intervensi lain yang lebih baru dan memberikan dampak lebih baik untuk anak dengan gejalan hambatan sosial.

\section{DAFTAR PUSTAKA}

Corey, M.S. \& Corey, G. (2006). Groups: Process and Practice. Belmont, CA: Thompson Brooks/Cole.

Blum, D.J \& Davis, T.E. (2010). The School Counselor's Book of List, Second Edition. USA: PB Printing.

Daeng, S. \& Dini, P. (1996). Metode Mengajar di Taman Kanak Kanak, Bagian 2. Jakarta: Depdikbud.

Departement Kesehatan RI. (2012). Pedoman Pelaksanaan: Stimulasi, Deteksi, dan Intervensi Dini Tumbuh Kembang Anak di Tingkat Pelayanan Kesehatan Dasar. Jakarta: Departemen Kesehatan, Direktorat Jendral Pembinaan Kementrian Masyarakat.

Hurlock, E. B. (1997). Perkembangan Anak. Edisi Keenam. Jilid 1. Jakarta: Penerbit Erlangga. 
Kavale, K.A \& Mostert, M.P. (2014). Social Skills Interventions for Individuals with Learning Disability. Winter. 27(3), hlm. 47-63.

Martin, G \& Pear, J. (2003). Behaviour Modification : What It Is And How To Do It (6 ${ }^{\text {th }}$ edition). New Jersey: Prentice-Hall Inc.

Nelson, R. W. \& Israel, A. C. (2006). Behaviour Disorders of Childhood sixth edition. New Jersey: Pearson Education, Inc.

Omrod, J. E. (2009). Psikologi Pendidikan. Jakarta: Penerbit Erlangga.

Prayitno, \& Amti, E. (2004). Dasar-Dasar Bimbingan dan Konseling. Jakarta: Rhineka Cipta.

Paternotte, A \& Buitelaar, J (Penerjemah: Julia Maria Van Tiel) (2008). ADHD: Attention Deficit Hyperactivity Disorder (Gejala, Diagnosis, Terapi, serta Penanganannya di Rumah dan di Sekolah). Jakarta: Prenada.

Rohayati, T. (2013). Pengembangan Perilaku Sosial Anak Usia Dini. Cakrawala Dini, 4(2), hlm. 131-137.

Santrock, J.W. (2002). Perkembangan Anak Jilid Kedua. Jakarta: Penerbit Erlangga.

Skinner. B. F. (1965). Science and Human Behaviour. New York: The Free Press.

Subandi, dkk. 2002. Psikoterapi, Pendekatan Konvensional dan Kontemporer. Yogyakarta: Pustaka Pelajar.

Sugiyono. (2013). Metode Penelitian Kuantitatif, Kualitatif, dan R\&D. Bandung: Alfabeta.

Sundel, M \& Sundel, S.S. (2005). Behaviour Change in the Human Services: Behaviour and Cognitive Principles and Applications. London: Sage Pub, Inc.

Theighbulem, O.T., Theighbulem, V.N., \& Igwebuike, D.(2011). The effect of token economy on academic achievement of secondery school students : implications for counselling. Proceeding of the 2011 International Conference on Teaching, Learning and Change.

Tim Penyusun Yayasan Suryakanti. (2003). Deteksi Dini Tumbuh Kembang Balita. Bandung: Yayasan Suryakanti.

Zirpoli, T.J. (2012). Behaviour Management Positive Application for Teachers. Sixth Edition. Boston : Pearson. 
24 | Afridah - Efektivitas Metode Token ... 